\title{
The Efficiency Improvement of Central European Corporate Milk Processors in 2008 - 2013
}

\author{
J. Špička \\ University of Economics, Prague, Czech Republic
}

\begin{abstract}
Anotace
Cílem článku je vyhodnotit vývoj technické efektivnosti českých, polských a slovenských zpracovatelů mléka v období 2008 - 2013 se záměrem identifikovat potenciální zdroje nízké konkurenceschopnosti českých a slovenských zpracovatelů mléka. Analýza byla založena na individuálních datech 130 zpracovatelů mléka (NACE 10.51). Soubor zahrnuje střední a velké zpracovatele. Deflovaná data o tržbách, materiálových nákladech, osobních nákladech a odpisech byla použita jako výstupy, resp. vstupy pro výpočet technické efektivnosti a technického pokroku. K výpočtu technické efektivnosti byla zvolena metoda DEA, Malmquistův index byl použit k odhadu změny v čase. Hypotézy byly testovány pomocí dvouvýběrového t-testu, analýzy rozptylu a Scheffeho testu. Výsledky ukazují, že čeští a slovenští zpracovatelé dosáhli nižšího tempa technického pokroku než polští zpracovatelé. Investiční aktivita významně neovlivnila změnu v efektivnosti. Doporučením je, aby čeští a slovenští zpracovatelé mléka efektivně využívali investiční dotace z Programu rozvoje venkova v letech 2014 - 2020 ke zvýšení technické efektivnosti, protože polští zpracovatelé mléka v období 2007 - 2013 české a slovenské zpracovatele v technické efektivnosti předčili.
\end{abstract}

\section{Klíčová slova}

Konkurenceschopnost, DEA, finanční poměrové ukazatele, Malmquistův index.

\begin{abstract}
The aim of the article is to evaluate the technical efficiency improvement of the Czech, Polish and Slovak corporate milk processors in the period 2008 - 2013 to identify the possible source of low competitiveness of the Czech and Slovak milk processors towards Poland. The analysis was based on individual data of $130 \mathrm{milk}$ processors (NACE 10.51). The sample covers medium-sized and large companies only. Deflated data on sales, material and energy costs, staff costs and depreciation were used as output and inputs for efficiency calculation. The DEA method was used for calculation of technical efficiency, Malmquist index estimated the efficiency change in time. Two-sample t-test and the analysis of variance enhanced by Sheffe's test verified the statistical hypotheses. The results proved that the Czech and Slovak milk processors had lower efficiency improvement than Polish companies. Investment activity did not significantly affect the efficiency improvement. The Czech and Slovak milk processors should effectively use quite big amount of public subsidies from the Rural Development Programme in the period 2014 - 2020 to improve the efficiency since the Polish companies outstripped the Czech and Slovak companies in the period 2007 - 2013.
\end{abstract}

\section{Keywords:}

Competitiveness, DEA, financial ratios, Malmquist index.

Špička, J. (2015) "The Efficiency Improvement of Central European Corporate Milk Processors in 2008 - 2013", AGRIS on-line Papers in Economics and Informatics, Vol. 7, No. 4, pp. 175 - 188 , ISSN 1804-1930.

\section{Introduction}

Milk and milk products are the essentials of human nutrition. The Central Europe is a region with long tradition of production and consumption of milk and milk products. There is quite strong competition between production capacities in the
Central Europe. Competitiveness of companies influences the competitiveness on national economy. Economy is competitive when producing goods and services which can withstand the test of international competition, i. e. generate a relatively high income and relatively high level of employment under the conditions 
of open economy (Nečadová, 2015). The balance of foreign trade is a good indicator of international competitiveness. According to the External Trade Database of the Czech Statistical Office, the foreign trade balance of the milk and milk products (codes 0401 - 0406 of Harmonized System 4-digits code) is positive between the Czech Republic and Slovakia (it raised from 948.9 mil. $\mathrm{CZK}$ to 2386.4 mil. $\mathrm{CZK}$ in the period 2008 - 2014) and negative between the Czech Republic and Poland (it decreased from -1 992.1 mil. CZK to -2523.9 mil. CZK). The comparative advantage of dairy products has been reduced. It indicates that the Czech Republic is not able to compete to the Polish milk processors whereas it is more competitive than Slovak companies. One of the possible reasons are low technical efficiency and low efficiency improvement.

The question of the technical efficiency and the efficiency improvement in agribusiness in the Central Europe was occupied by many authors. Most papers have dealt with the technical efficiency of agricultural companies in recent years (Čechura, 2012; Bojnec et al., 2014; Nowak, Kijek, Domańska, 2015; Špička, Machek, 2015; Baráth, Ferto, 2015; Maxová, Žáková Kroupová, 2015). Unfortunately, only a few authors focused on food processing industry (Forsund, Hjalmarsson, 1979; Ferrier, Porter 1991; Daňková, Bosáková, 2005, Nastasenko, 2010; Čechura, Hockman, 2010). Čechura and Malá (2014) analyzed the differences in the technology and the technical efficiency of Czech and Slovak processing companies in the period 2003-2012. They compared oils, dairy, milling and other sectors (not specifically the meat processing industry). They found significant differences in technology between the Czech and Slovak dairy industries. This especially concerns the productivity parameter, technological change and the cost share of materials. All the estimated country-specific effects are negative for Slovak dairy companies. An analysis of the development of technical efficiency indicates that the best Czech firms in the dairy sector have a strong market position, and companies with low efficiency have lost their position in the market for dairy products. In the Slovak Republic, an increase in the competitiveness of dairy companies is evident. Moreover, Slovak milk processors have the highest variability in technical efficiency.

So, it is very topical to evaluate a technical efficiency and efficiency improvement in the milk processing industry. The problem of negative foreign trade balance between the Czech Republic and Poland is a good reason to make the analysis. The aim of the paper is to evaluate the technical efficiency improvement of the Czech, Slovak and Polish corporate milk processors in the period 2008 - 2013. The analysis covers medium-sized and large companies only since they have a potential for foreign trade rather than small processors. The article also deals with the differences in financial indicators between companies with high and low efficiency improvement and among Czech, Slovak and Polish companies.

\section{Methodology}

As Špička and Machek (2015) introduced, efficiency measurement is often carried out from two perspectives: total factor productivity (TFP) which takes into account all possible inputs and outputs of an industry (firm, process), multifactor productivity (MFP) which deals with the relationship between output and multiple input factors, and partial factor productivity (PFP) which deals with the productivities of individual inputs. The article deals with multifactor productivity (MFP) which deals with the relationship between output and multiple input factors. MFP and Malmquist index to quantify change in a company's efficiency over a period of time.

A producer can be defined as an economic agent transforming a set of inputs $\mathrm{x}=\left(x_{1}, x_{2}, \ldots, x_{n}\right)$ into a set of outputs $\mathrm{y}=\left(y_{1}, y_{2}, \ldots, y_{m}\right)$. Generally, we consider the components of these vectors to be strictly positive. In order to define the Malmquist index of productivity (Caves et al., 1982), consider a period during which the production has changed from $\left(\mathrm{x}_{t}, \mathrm{y}_{t}\right)$ to $\left(\mathrm{x}_{t+1}, \mathrm{y}_{t+1}\right)$. Let's suppose the outputmaximizing approach which means the lesser the distance from a production frontier, the better the efficiency score. The Malmquist index of productivity for period $t$, respectively for period $t+1$, would be the ratios.

$$
\begin{aligned}
& M_{t}\left(\mathbf{x}_{t}, \mathbf{y}_{t}, \mathbf{x}_{t+1}, \mathbf{y}_{t+1}\right)=\frac{D_{t}\left(\mathbf{x}_{t+1}, \mathbf{y}_{t+1}\right)}{D_{t}\left(\mathbf{x}_{t}, \mathbf{y}_{t}\right)} \\
& M_{t+1}\left(\mathbf{x}_{t}, \mathbf{y}_{t}, \mathbf{x}_{t+1}, \mathbf{y}_{t+1}\right)=\frac{D_{t+1}\left(\mathbf{x}_{t+1}, \mathbf{y}_{t+1}\right)}{D_{t+1}\left(\mathbf{x}_{t}, \mathbf{y}_{t}\right)} ;
\end{aligned}
$$

where $D_{t}$ denotes the value of the distance function in period $t$. If the technology has changed during the period, these two indexes would result in different values. Therefore, it is common to employ the geometric mean of the two indexes and specify the Malmquist index of productivity as

$$
M\left(\mathbf{x}_{t}, \mathbf{y}_{t}, \mathbf{x}_{t+1}, \mathbf{y}_{t+1}\right)=\sqrt{\frac{D_{t}\left(\mathbf{x}_{t+1}, \mathbf{y}_{t+1}\right)}{D_{t}\left(\mathbf{x}_{t}, \mathbf{y}_{t}\right)} \times \frac{D_{t+1}\left(\mathbf{x}_{t+1}, \mathbf{y}_{t+1}\right)}{D_{t+1}\left(\mathbf{x}_{t}, \mathbf{y}_{t}\right)}}
$$


The index can be further decomposed in the product of two terms (Färe et al., 1992):

$$
\begin{aligned}
& M\left(\mathbf{x}_{t}, \mathbf{y}_{t} \mathbf{x}_{t+1}, \mathbf{y}_{t+1}\right)=\sqrt{\frac{D_{t}\left(\mathbf{x}_{t+1}, \mathbf{y}_{t+1}\right)}{D_{t}\left(\mathbf{x}_{t}, \mathbf{y}_{t}\right)} \times \frac{D_{t+1}\left(\mathbf{x}_{t+1}, \mathbf{y}_{t+1}\right)}{D_{t+1}\left(\mathbf{x}_{t}, \mathbf{y}_{t}\right)}}= \\
& =\sqrt{\frac{D_{t+1}\left(\mathbf{x}_{t+1}, \mathbf{y}_{t+1}\right)}{D_{t}\left(\mathbf{x}_{t}, \mathbf{y}_{t}\right)} \times \frac{D_{t+1}\left(\mathbf{x}_{t+1}, \mathbf{y}_{t+1}\right)}{D_{t}\left(\mathbf{x}_{t}, \mathbf{y}_{t}\right)} \times \frac{D_{t}\left(\mathbf{x}_{t}, \mathbf{y}_{t}\right)}{D_{t+1}\left(\mathbf{x}_{t+1}, \mathbf{y}_{t+1}\right)} \times \frac{D_{t}\left(\mathbf{x}_{t+1}, \mathbf{y}_{t+1}\right)}{D_{t+1}\left(\mathbf{x}_{t}, \mathbf{y}_{t}\right)}}= \\
& =\frac{D_{t+1}\left(\mathbf{x}_{t+1}, \mathbf{y}_{t+1}\right)}{D_{t}\left(\mathbf{x}_{t}, \mathbf{y}_{t}\right)} \times \sqrt{\frac{D_{t}\left(\mathbf{x}_{t}, \mathbf{y}_{t}\right)}{D_{t+1}\left(\mathbf{x}_{t}, \mathbf{y}_{t}\right)} \times \frac{D_{t}\left(\mathbf{x}_{t+1}, \mathbf{y}_{t+1}\right)}{D_{t+1}\left(\mathbf{x}_{t+1}, \mathbf{y}_{t+1}\right)}}= \\
& \Delta T E\left(\mathbf{x}_{t}, \mathbf{y}_{t} \mathbf{x}_{t+1}, \mathbf{y}_{t+1}\right) \times \Delta T\left(\mathbf{x}_{t}, \mathbf{y}_{t} \mathbf{x}_{t+1}, \mathbf{y}_{t+1}\right)
\end{aligned}
$$

The first term $\triangle T E$ reflects the impact of changes in technical efficiency which means that $\triangle T E>1$ as technical efficiency improves and $\triangle T E<1$ as technical efficiency deteriorates. The second term $\Delta T$ captures the changes in technology (technical change) which can be expressed by the ability of a firm to produce more (or less) with a given level of inputs in $\mathrm{t}$ related to the levels feasible in $t+1 . \Delta T$ is the geometric mean of two term, when the first term compares the two periods in terms of period $\mathrm{t}$ data, and the second term the two periods in terms of period $t+1$ data. $\Delta T>1$ as technical progress occurred between periods, while $\Delta T<0$ as technical regress occurred between the two periods.

The input-oriented Data Envelopment Analysis model assumes the variable returns to scale (DEAVRS method ${ }^{1}$ ). The issue of the returns to scale concerns what happens to units' outputs when they change the amount of inputs that they are using to produce their outputs. Under the assumption of the variable returns to scale a unit found to be inefficient has its efficiency measured relative to other units in the data-set of a similar scale size only.

Three inputs and one output per company were used for efficiency calculation.

- Output $=$ Sales, i.e. the financial value of production sold to the customers excluding the Value Added Tax.

- Input $1=$ Materials and Energy, i.e. the financial value of material and energy consumption.

- Input $2=$ Staff costs, i.e. the financial value of wages including all payments of employees and employers.

- Input $3=$ Depreciation and amortization, i.e. the financial value of consumption of the long-term assets within each year.

In order to remove the influence of price development, outputs and three inputs (expressed in monetary units) were deflated using output and input price indices. The indices were taken from the Eurostat database of price indices. The variables are deflated in each country as follows:

- Sales: Eurostat - Producer prices in industry, total - Processing of milk and milk products $($ EU-27, $2010=100)$.

- Material and energy: Eurostat - Price indices of agricultural products, output - Milk (CZ, PL, SK, $2010=100$ ). Milk is the main input in the milk processing industry.

- Staff costs: Eurostat - Labor input in industry, total - Manufacture of food products - Gross wages and salaries (CZ, PL, SK, $2010=100)$.

- Capital consumption (depreciation): Eurostat - Producer prices in industry, total - Capital goods $(\mathrm{CZ}, \mathrm{PL}, \mathrm{SK}, 2010=100)$.

1. Detection of outliers. Outliers in the original sample were detected through the Rosner's ESD many-outliers test for Labor productivity, Material and energy productivity and Capital productivity (Rosner, 2011).

- $\quad$ Labor productivity $=$ Sales $/$ Staff costs

- Material and energy productivity = Sales/ Materials

- Capital productivity $=$ Sales/Depreciation and amortization

Total 16 of 146 companies were removed as outliers, i.e. 130 companies remained as the final sample for efficiency analysis.

2. Calculation of Malmquist index and input-oriented technical efficiency (Caves et al., 1982). The method is described at the beginning of this chapter. The DEA method and Malmquist index was applied through Banxia Frontier Analyst 4.

3. Economic indicators of the individual companies in the sample. The following economic ratios and indicators were calculated.

A. Investment Activity $(\%)=($ Fixed assets - Fixed assets $_{\mathrm{t}-1}+$ Depreciation $\left._{\mathrm{t}}\right) /$ Fixed assets $_{\mathrm{t}-1} * 100$

B. Profitability ratios

- ROCE using P/L before tax (\%) $=($ Profit before tax + Interest paid $) /$ (Shareholders funds + Non-current liabilities) * 100

- ROA using P/ L before tax (\%) $=($ Profit before tax $/$ Total assets $) * 100$

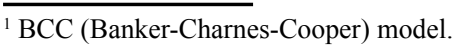


- Profit margin $(\%)=($ Profit before tax $/$ Operating revenue) $* 100$

C. Turnover ratios

- Net assets turnover $(\mathrm{x})=$ Operating revenue/(Shareholders funds + Noncurrent liabilities)

- Stock turnover $(\mathrm{x})=$ Operating revenue/ Stocks

D. Payment balance

- Credit period (days) $=$ (Creditors/ Operating revenue) $* 360$

- Collection period (days) $=$ (Debtors/ Operating revenue) $* 360$

E. Liquidity and solvency ratios

- Liquidity ratio $(\mathrm{x})=($ Current assets - Stocks) / Current liabilities

- Solvency ratio (asset based, \%) $=$ (Shareholders funds $/$ Total assets $)$ * 100

F. Capital structure

- Current liabilities / Total assets (\%)

- Loans / Total assets (\%)

4. Comparison of differences between progressive and other milk processors. The two-sample t-test compare the distribution between the two equal-sized groups - progressive companies with higher values of mean Malmquist index (group A) and other companies with low values of mean Malmquist index (group B) in the period $2008-2013$. The two-sided test of hypotheses is applied. H0: There is no statistical difference between the distributions A and B. HA: There is a statistical difference between the distributions $\mathrm{A}$ and $\mathrm{B}$. The statistical analysis is processed automatically by software NCSS 10 .

5. Comparison of multiple differences in the sample (a country view). The statistical analysis is processed automatically by software NCSS 10. The one-way analysis of variance compares the means of two or more groups to determine if at least one group mean is different from the others. It is important to notice that the assumption of simple random samples is not complied since the sample contains only companies with complete financial statements in the period $2008-2013$. However, if we analyze medium and large corporate milk processors only, we can assume the sample as representative and random. To verify the rejection or acceptation of the null hypothesis, the F-test is used. Decisions are made by comparing the maximum first type error (the p-value), based on our data, and errors of the first type of alpha, which we have set before testing. Following hypotheses were tested: H0: All group data distributions are the same; HA: At least one group has observations that tend to be greater than those of the other groups.

6. Multiple Comparison Procedure. Given that the analysis of variance test finds a significant difference among treatment means, the next task is to determine which treatments are different. We chose Scheffe's test. It can be used to examine all possible comparisons among $\mathrm{k}$ means or just to look at all pairs as done here. It controls the overall or experimentwise error rate.

\section{Data}

The analysis used data from the Amadeus database that provides comparable financial information for public and private companies across Europe. The companies with specialization in the branch 10.51 Operation of dairies and cheese making in the Czech Republic, Poland and Slovakia were in focus. The analysis covered the period $2008-2013$ that represents the "old" programming period of the Rural Development Programme (RDP). The article focused on the medium and large corporations since they have produced most value of processed milk in both countries. Moreover, small companies do not usually export the products. Not all companies generated by Amadeus database released complete balance sheet and income statement in the period 2008 - 2013. So, 30 Czech companies, 98 Polish companies and 18 Slovak companies had complete financial statements in that period (i.e. 146 companies in total). Afterwards, the Rosner's ESD many-outliers test detected 16 outliers. So, the final sample of 130 companies entered into the analysis. The table 1 contains the number and turnover (operating revenues) of the companies in the sample and in the population according to the official statistics by Eurostat and the Czech Statistical Office.

The three largest milk processors (turnover in 2013, majority owner) in the sample are:

- Czech Republic: Mlékárna Pragolaktos, a. s. (201.43 mil. EUR, Sachsenmilk Leppersdorf GmbH, Germany), MADETA a. s. (194.98 mil. EUR, Faltha Investment, SA, British Virgin Islands), OLMA, a. s. (124.29 mil. 


\begin{tabular}{|l|c|c|c|}
\hline & Sample & Population & Sample / Population (\%) \\
\hline Number of enterprises (CZ) & 27 & 35 & 77.1 \\
\hline Number of enterprises (PL) & 87 & 145 & 60 \\
\hline Number of enterprises (SK) & 16 & 16 & 100 \\
\hline Number of enterprises (Total) & 130 & 196 & 66.3 \\
\hline Turnover (CZ), th. EUR & 1076370.2 & 1534956.3 & 70.1 \\
\hline Turnover (PL), th. EUR & 3533638.5 & 6254600.0 & 56.5 \\
\hline Turnover (SK), th. EUR & 489685.0 & 489685.0 & 100.0 \\
\hline Turnover (Total), th. EUR & 5099693.7 & 8279241.3 & 61.6 \\
\hline
\end{tabular}

Source: Eurostat, Czech Statistical Office, Amadeus, author's calculation

Table 1: The comparison of the sample and the population (2012) - 50 and more employees.

\begin{tabular}{|l|r|r|c|}
\hline Indicator & Total assets (EUR) & Turnover (EUR) & EBITDA (EUR) \\
\hline Mean & 20001899.30 & 39228412.56 & 1918081.58 \\
\hline Median & 6143890.07 & 15880977.76 & 552157.28 \\
\hline Standard Deviation & 64106993.78 & 84707849.92 & 4775907.42 \\
\hline Standard Error & 5622555.30 & 7429369.91 & 418874.79 \\
\hline Minimum & 14896.50 & 43773.00 & -57551.37 \\
\hline Maximum & 655945237.32 & 626338062.56 & 43007411.25 \\
\hline 95\% LCL & 8877535.93 & 24529222.24 & 1089327.54 \\
\hline 95\% UCL & 31126262.66 & 53927602.87 & 2746835.61 \\
\hline
\end{tabular}

Source: author's calculation

Table 2. Descriptive statistics of the sample (mean of the 2008 - 2013)

\section{EUR, Agrofert, a.s., Czech Republic)}

- Poland: Spółdzielnia Mleczarska Mlekovita (804.91 mil. EUR, Spółdzielnia Mleczarska Mlekovita, Poland), Mlekpol Spółdzielnia Mleczarska (782.97 mil. EUR, Mlekpol Spoldzielnia Mleczarska, Poland), Danone Sp. z o. o. (349.69 mil. EUR, Danone, France).

- Slovakia: Rajo, a. s. (160.06 mil. EUR, Meggle AG, Germany), Syráren̆ Bel Slovensko, a. s. (77.70 mil. EUR, Fromageries Bel, SA, France), Tatranská Mliekareň, a. s. (74.73 mil. EUR, Ing. Mikuláš Bobák Slovakia).

There is a big difference in size between the biggest milk processors in Poland, the Czech Republic and Slovakia. Polish milk processors are bigger than Czech and Slovak companies. Morevover, the biggest Polish milk processors are cooperatives unlike Czech and Slovak companies which are owned by one major national or foreign investor.

The table 2 informs about basic descriptive statistics of the sample. The book value of total assets, turnover (operating revenues) and EBITDA (Earnings before Taxes, Depreciation and Amortization) are key indicators of firm size.

Descriptive statistics reveal quite wide range of the sample. It contains both profitable and loss-making companies. Eight companies in the sample were in loss in the period 2008 - 2013. However, the loss is not so deep to make bankruptcy.

\section{Results and discussion}

The results describe differences between two equal-size groups according to the value of the mean Malmquist index ( $2 \times 27$ companies). The difference in the Malmquist index was tested both between two equal-size groups (A, B) and between Czech and Polish companies. Moreover, development of the technical efficiency over time is described in the Czech Republic, Poland and Slovakia through the analysis of variance. A description of Malmquist index and investment activity (tables $3,4)$ is followed by the comparison of technical efficiency development (Fig. 1 and 2). Afterwards, the development of partial productivity is discussed.

The companies in the group A with mean Malmquist index 1.074 experienced more dynamic growth of the efficiency than companies in the group B with mean Malmquist index 0.992. The difference is significant at $\alpha=0.01$. The analysis of variance revealed the significantly higher technical improvement of Polish milk processors 


\begin{tabular}{|lccccc|}
\hline Groups & Statistics & $\begin{array}{c}\text { Group A } \\
(\mathrm{N}=65)\end{array}$ & $\begin{array}{c}\text { Group B } \\
(\mathrm{N}=65)\end{array}$ & t-statistic & p-value \\
\hline Malmquist index & Mean & 1.074 & 0.992 & 13.7093 & 0.0000 \\
& $\mathrm{SD}$ & 0.036 & 0.032 & & \\
\hline Countries & & $\mathrm{CZ}(\mathrm{N}=27)$ & $\mathrm{PL}(\mathrm{N}=87)$ & $\mathrm{SK}(\mathrm{N}=16)$ & \\
\hline Malmquist index & Mean & 0.996 & 1.056 & 0.974 & \\
& $\mathrm{SD}$ & 0.065 & 0.035 & 0.023 & \\
\hline ANOVA & $\mathrm{DF}$ & Sum of Sq. & Mean Sq. & F-Ratio & p-value \\
\hline Between (Country) & 2 & 0.138 & 0.069 & 38.8173 & 0.0000 \\
Scheffe & $\mathrm{DF}=127 \mathrm{MSE}=0.001772458$ & & CZ-PL, SK-PL & \\
\hline
\end{tabular}

Source: author's calculation

Table 3. Statistics of the Malmquist index.

\begin{tabular}{|lccccc|}
\hline Groups & Statistics & $\begin{array}{c}\text { Group A } \\
(\mathrm{N}=65)\end{array}$ & $\begin{array}{c}\text { Group B } \\
(\mathrm{N}=65)\end{array}$ & t-statistic & p-value \\
\hline Investment activity & Mean & 16.865 & 19.390 & -0.7557 & 0.4512 \\
& $\mathrm{SD}$ & 16.982 & 20.907 & & \\
\hline Countries & & $\mathrm{CZ}(\mathrm{N}=27)$ & PL $(\mathrm{N}=87)$ & $\mathrm{SK}(\mathrm{N}=16)$ \\
\hline Investment activity & Mean & 24.894 & 16.439 & 15.890 & 11.962 \\
& $\mathrm{SD}$ & 26.357 & 17.004 & F-Ratio & p-value \\
\hline ANOVA & $\mathrm{DF}$ & Sum of Sq. & Mean Sq. & 2.2041 & 0.11456 \\
\hline Between (Country & 2 & 1564.514 & 782.257 & No differences at $\alpha=0.05$. \\
\hline Scheffe & $\mathrm{DF}=127 \mathrm{MSE}=354.9117$ & & \\
\hline
\end{tabular}

Source: author's calculation

Table 4: Statistics of the investment activity.

$(\mathrm{MI}=1.056)$. Alternatively, there is no significant difference between Czech and Slovak Malmquist index. This is important finding that could partly explain the negative and worsen trade balance between CZ-SK and Poland. One of the possible reasons of the higher technical improvement of Polish milk processors could be an investment activity. Nevertheless, table 2 did not establish any statistically significant difference between the two groups and countries. So, it could imply that the investment expenditures are differently efficient, probably more in Poland. Other possible reason of more dynamic technical efficiency in Poland could be a quality of management. However, such conclusion requires qualitative research.

Figures 1 and 2 show a development of the technical efficiency in each year of the period 2008 - 2013.

Figures demonstrate that companies in the group A had strongly lower technical efficiency than group B in 2008 - 2009. Both groups improved the technical efficiency at the beginning of the "old" RDP programming period after their investments launched. Then, group A and B improved the technical efficiency in the same direction and kept their technical efficiency at the similar level between $83 \%$ and $88 \%$ in the period $2010-2012$. In 2013, the technical efficiency of the companies in the group B slowly decreased at $86 \%$ whereas the technical efficiency of the group A reached $91.7 \%$. Regarding international comparison (fig. 2), the development of the technical efficiency of the Polish companies is different from Czech and Slovak. Polish companies have continuously increased the technical efficiency from $66.6 \%$ (2008) to $90.9 \%$ (2013). The technical efficiency of Czech and Slovak milk processors has varied without any significant trend. Thus, Polish milk processors can be considered as very successful in technical efficiency improvement. The fig. 2 clearly shows that there are some problems with technical efficiency of milk processors in the Czech Republic and Slovakia.

Tables $5 \mathrm{a}, 5 \mathrm{~b}$ and $5 \mathrm{c}$ disaggregate the technical efficiency into the partial efficiency of thee inputs - materials (material and energy), staff costs and capital consumption (depreciation).

There are significant differences of sales to materials ratio between group A and B (at $\alpha=0.1$ ) 


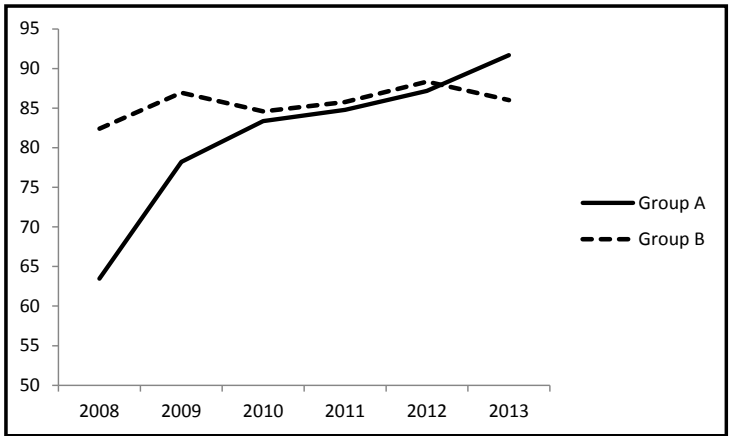

Source: author's calculation

Figure 1: Differences in the technical efficiency score between Group A and B.

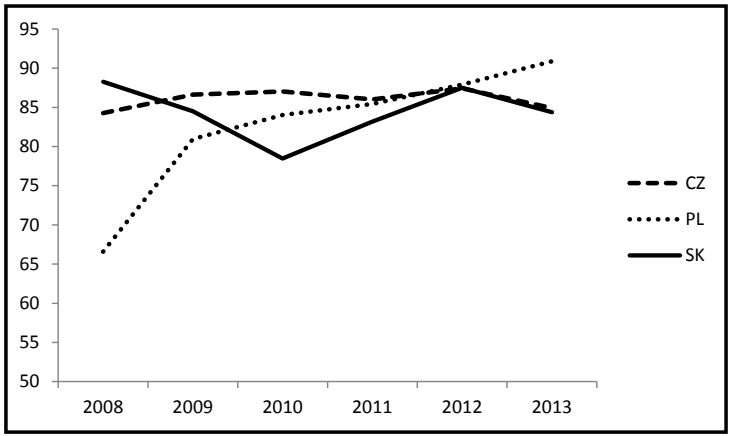

Source: author's calculation

Figure 2: Differences in the technical efficiency score in CZ, PL and SK.

\begin{tabular}{|lccccc|}
\hline Groups & Statistics & $\begin{array}{c}\text { Group A } \\
(\mathrm{N}=65)\end{array}$ & $\begin{array}{c}\text { Group B } \\
(\mathrm{N}=65)\end{array}$ & t-statistic & p-value \\
\hline Materials and energy & Mean & 1.232 & 1.355 & -2.8875 & 0.0046 \\
productivity & $\mathrm{SD}$ & 0.100 & 0.330 & & \\
\hline Countries & & $\mathrm{CZ}(\mathrm{N}=27)$ & $\mathrm{PL}(\mathrm{N}=87)$ & $\mathrm{SK}(\mathrm{N}=16)$ \\
\hline Materials and energy & Mean & 1.426 & 1.254 & 1.289 & 0.117 \\
productivity & $\mathrm{SD}$ & 0.481 & 0.120 & F-Ratio & p-value \\
\hline ANOVA & $\mathrm{DF}$ & $\mathrm{Sum}$ of Sq. & Mean Sq. & 5.1821 & 0.0069 \\
\hline Between (Country) & 2 & 0.609 & 0.305 & CZ-PL & \\
Scheffe & $\mathrm{DF}=127 \mathrm{MSE}=0.05879883$ & & & \\
\hline
\end{tabular}

Source: author's calculation

Table 5a: Statistics of the partial productivity - materials and energy.

\begin{tabular}{|lccccc|}
\hline Groups & Statistics & Group A & Group B & t-statistic & p-value \\
& & $(\mathrm{N}=65)$ & & \\
\hline Labour productivity & Mean & 17.801 & 14.874 & 1.5477 & 0.1242 \\
& $\mathrm{SD}$ & 13.050 & 7.879 & & \\
\hline Countries & & $\mathrm{CZ}(\mathrm{N}=27)$ & PL $(\mathrm{N}=87)$ & $\mathrm{SK}(\mathrm{N}=16)$ \\
\hline Labour productivity & Mean & 14.883 & 17.445 & 12.767 \\
& $\mathrm{SD}$ & 10.638 & 11.404 & 6.612 & $\mathrm{p}$-value \\
\hline ANOVA & $\mathrm{DF}$ & $\mathrm{Sum}$ of Sq. & Mean Sq. & F-Ratio & 0.2099 \\
\hline Between (Country) & 2 & 367.823 & 183.911 & No differences at $\alpha=0.05$ \\
Scheffe & $\mathrm{DF}=127 \mathrm{MSE}=116.3952$ & & \\
\hline
\end{tabular}

Source: author's calculation

Table 5b. Statistics of the partial productivity - labour productivity.

\begin{tabular}{|c|c|c|c|c|c|}
\hline Groups & Statistics & $\begin{array}{l}\text { Group A } \\
(\mathrm{N}=65)\end{array}$ & $\begin{array}{l}\text { Group B } \\
(\mathrm{N}=65)\end{array}$ & t-statistic & $\mathrm{p}$-value \\
\hline \multirow[t]{2}{*}{ Capital productivity } & Mean & 50.253 & 44.445 & 1.4437 & 0.1513 \\
\hline & SD & 23.641 & 22.202 & & \\
\hline Countries & & $\mathrm{CZ}(\mathrm{N}=27)$ & PL $(\mathrm{N}=87)$ & SK $(N=16)$ & \\
\hline \multirow[t]{2}{*}{ Capital productivity } & Mean & 49.624 & 49.811 & 30.122 & \\
\hline & SD & 27.495 & 21.881 & 12.025 & \\
\hline ANOVA & $\mathrm{DF}$ & Sum of Sq. & Mean Sq. & F-Ratio & p-value \\
\hline Between (Country) & 2 & 5415.331 & 2707.665 & 5.4585 & 0.0053 \\
\hline Scheffe & \multicolumn{2}{|c|}{$\mathrm{DF}=127 \mathrm{MSE}=496.0486$} & & CZ-SK, PL-SK & \\
\hline
\end{tabular}

Source: author's calculation

Table 5c: Statistics of the partial productivity - productivity of capital consumption (depreciation). 
and between Czech and Polish companies. The Czech companies have significantly higher productivity of material and energy than Polish milk processors. The companies in the group A had lower material productivity than the group B. However, the group A had higher labour productivity and higher capital productivity but not significantly. It could indicate some substitution between material and labour (human and machine). Slovak companies had significantly lower capital productivity than Czech and Polish milk processors. The main reason of dynamic technical improvement of Polish companies was growing capital productivity, especially in 2012 and 2013.

Next tables show differences in financial ratios between the two groups and three countries. The section starts with three profitability indicators - ROCE, ROA and Profit Margin.

ROCE is the important indicator because it expresses how much profit before taxes and interests the company generate from one unit of long-term capital of shareholders and creditors. Table 6 establishes significant differences in ROCE between Czech, Polish and Slovak companies. The Czech companies had significantly higher ROCE than milk processors in other countries. Another indicator of profitability, ROA, measures profit per total assets including current assets. There is no significant difference between the two groups A and B. However, the Czech companies had

\begin{tabular}{|c|c|c|c|c|c|}
\hline Groups & Statistics & $\begin{array}{l}\text { Group A } \\
(\mathrm{N}=65)\end{array}$ & $\begin{array}{l}\text { Group B } \\
(\mathrm{N}=65)\end{array}$ & t-statistic & $\mathrm{p}$-value \\
\hline \multirow[t]{2}{*}{ ROCE (\%) } & Mean & 4.616 & 7.369 & -0.7902 & 0.4310 \\
\hline & SD & 22.494 & 15.192 & & \\
\hline Countries & & $\mathrm{CZ}(\mathrm{N}=27)$ & $\operatorname{PL}(\mathrm{N}=87)$ & SK $(N=16)$ & \\
\hline \multirow[t]{2}{*}{ ROCE (\%) } & Mean & 15.905 & 4.370 & -1.674 & \\
\hline & SD & 18.613 & 18.527 & 18.134 & \\
\hline ANOVA & DF & Sum of Sq. & Mean Sq. & F-Ratio & $\mathrm{p}$-value \\
\hline Between (Country) & 2 & 3551.124 & 1775.562 & 5.1887 & 0.0069 \\
\hline Scheffe & \multicolumn{2}{|c|}{$\mathrm{DF}=127 \quad \mathrm{MSE}=342.196$} & \multicolumn{3}{|c|}{ CZ-PL, CZ-SK } \\
\hline Groups & Statistics & $\begin{array}{l}\text { Group A } \\
(\mathrm{N}=65)\end{array}$ & $\begin{array}{l}\text { Group B } \\
(\mathrm{N}=65)\end{array}$ & t-statistic & p-value \\
\hline \multirow[t]{2}{*}{ ROA (\%) } & Mean & 2.833 & 3.032 & -0.1351 & 0.8927 \\
\hline & SD & 7.993 & 8.825 & & \\
\hline Countries & & $\mathrm{CZ}(\mathrm{N}=27)$ & PL $(\mathrm{N}=87)$ & $\mathrm{SK}(\mathrm{N}=16)$ & \\
\hline \multirow[t]{2}{*}{ ROA (\%) } & Mean & 6.078 & 2.831 & -1.821 & \\
\hline & $\mathrm{SD}$ & 6.978 & 8.384 & 8.696 & \\
\hline ANOVA & $\mathrm{DF}$ & Sum of Sq. & Mean Sq. & F-Ratio & $\mathrm{p}$-value \\
\hline Between (Country) & 2 & 629.592 & 314.796 & 4.7341 & 0.0104 \\
\hline Scheffe & \multicolumn{2}{|c|}{$\mathrm{DF}=127 \mathrm{MSE}=66.49523$} & \multicolumn{3}{|c|}{ CZ-SK } \\
\hline Groups & Statistics & $\begin{array}{l}\text { Group A } \\
(\mathrm{N}=65)\end{array}$ & $\begin{array}{l}\text { Group B } \\
(\mathrm{N}=65)\end{array}$ & t-statistic & p-value \\
\hline \multirow[t]{2}{*}{ Profit Margin } & Mean & 0.778 & 0.747 & 0.0385 & 0.9694 \\
\hline & SD & 3.118 & 5.631 & & \\
\hline Countries & & $\mathrm{CZ}(\mathrm{N}=27)$ & PL $(\mathrm{N}=87)$ & SK $(\mathrm{N}=16)$ & \\
\hline \multirow[t]{2}{*}{ Profit Margin } & Mean & 2.222 & 0.630 & -0.979 & \\
\hline & SD & 4.335 & 4.629 & 3.764 & \\
\hline ANOVA & DF & Sum of Sq. & Mean Sq. & F-Ratio & $\mathrm{p}$-value \\
\hline Between (Country) & 2 & 107.564 & 53.782 & 2.6849 & 0.07210 \\
\hline Scheffe & $\mathrm{DF}=127 \mathrm{M}$ & 0.03167 & & No differences & $=0.05$ \\
\hline
\end{tabular}

Source: author's calculation 
significantly higher ROA than Slovak companies.

The results of technical efficiency and profitability confirm that productivity (efficiency) and financial performance do not necessarily move in the same direction (Machek, 2014) since there is a different methodology of financial ratios and construction of productivity indices.

The ROA can be divided into profit margin and turnover ratios. Profit margin does not differ between the group A and B. Moreover, there are no significant differences between countries at $\alpha=0.05$.

Statistics of turnover ratios - net assets turnover and stock turnover - are described in the table 7 . Stock turnover is very important indicator of business activity in the field of material and product utilization in the manufacturing industry.

There are no significant differences in turnover ratios between group $\mathrm{A}$ and $\mathrm{B}$. The Czech companies had the highest net assets turnover but not significantly at $\alpha=0.05$. Stock turnover is higher in the group A. Slovak milk processors had the highest stock turnover. Despite no significant differences in turnover ratios, there are some indications of profitability determinants between countries. The Czech Republic had the highest profitability (ROA, ROCE). It was caused by higher profit margin. It means that $\mathrm{Czech}$ milk processors get more profit from one EUR of selling price than companies in Poland and Slovakia. Alternatively, the lowest profitability had Slovak milk processors which were in loss in the period 2008 - 2013. They prefer quick stock turnover at the expense of profit margin. This is a specific strategy which could lead to problems with competitiveness. It seems that Polish milk processors had balanced marketing strategy.

Next tables present differences in quality of financial management through indicators of debt management and solvency. Table 8 informs about credit period and collection period.

The credit period is the time frame between when a producer purchases inputs and when the producer's payment is due. The companies in the group B had significantly longer credit period than companies in the group A. In other words, group A had better payment morale than group B. When comparing countries, the credit period in Poland was shorter than in the Czech Republic and significantly lower than in Slovakia. It seems that Polish milk processor had different debt strategy from the Czech and Slovak companies.

\begin{tabular}{|c|c|c|c|c|c|}
\hline Groups & Statistics & $\begin{array}{l}\text { Group A } \\
(\mathrm{N}=65)\end{array}$ & $\begin{array}{l}\text { Group B } \\
(\mathrm{N}=65)\end{array}$ & t-statistic & p-value \\
\hline \multirow{2}{*}{$\begin{array}{l}\text { Net Assets } \\
\text { Turnover (x) }\end{array}$} & Mean & 5.996 & 5.693 & \multirow[t]{2}{*}{0.3179} & \multirow[t]{2}{*}{0.7511} \\
\hline & SD & 5.137 & 5.701 & & \\
\hline Countries & & $\mathrm{CZ}(\mathrm{N}=27)$ & $\operatorname{PL}(\mathrm{N}=87)$ & $\operatorname{SK}(\mathrm{N}=16)$ & \\
\hline \multirow{2}{*}{$\begin{array}{l}\text { Net Assets } \\
\text { Turnover (x) }\end{array}$} & Mean & 7.612 & 5.212 & 6.304 & \\
\hline & SD & 8.930 & 2.867 & 7.612 & \\
\hline ANOVA & DF & Sum of Sq. & Mean Sq. & F-Ratio & $\mathrm{p}$-value \\
\hline Between (Country) & 2 & 122.562 & 61.281 & 2.1327 & 0.12274 \\
\hline Scheffe & \multicolumn{2}{|c|}{$\mathrm{DF}=127 \quad \mathrm{MSE}=28.73414$} & & \multicolumn{2}{|c|}{ No differences at $\alpha=0.05$} \\
\hline \multirow[t]{2}{*}{ Groups } & Statistics & Group A & Group B & \multirow[t]{2}{*}{ t-statistic } & \multirow[t]{2}{*}{ p-value } \\
\hline & & $(\mathrm{N}=65)$ & $(\mathrm{N}=65)$ & & \\
\hline \multirow[t]{2}{*}{ Stock Turnover (x) } & Mean & 37.459 & 29.516 & \multirow[t]{2}{*}{0.7958} & \multirow[t]{2}{*}{0.4276} \\
\hline & SD & 54.683 & 59.041 & & \\
\hline Countries & & $\mathrm{CZ}(\mathrm{N}=27)$ & $\mathrm{PL}(\mathrm{N}=87)$ & $\mathrm{SK}(\mathrm{N}=16)$ & \\
\hline \multirow[t]{2}{*}{ Stock Turnover (x) } & Mean & 18.873 & 35.708 & 46.076 & \\
\hline & SD & 8.496 & 48.262 & 117.074 & \\
\hline ANOVA & DF & Sum of Sq. & Mean Sq. & F-Ratio & p-value \\
\hline Between (Country) & 2 & 8731.277 & 4365.639 & 1.3596 & 0.26047 \\
\hline Scheffe & \multicolumn{3}{|c|}{$\mathrm{DF}=127 \mathrm{MSE}=3210.915$} & \multicolumn{2}{|c|}{ No differences at $\alpha=0.05$} \\
\hline
\end{tabular}

Source: author's calculation

Table 7: Statistics of the turnover ratios. 


\begin{tabular}{|c|c|c|c|c|c|}
\hline Groups & Statistics & $\begin{array}{l}\text { Group A } \\
(\mathrm{N}=65)\end{array}$ & $\begin{array}{l}\text { Group B } \\
(\mathrm{N}=65)\end{array}$ & t-statistic & p-value \\
\hline \multirow{2}{*}{$\begin{array}{l}\text { Credit Period } \\
\text { (days) }\end{array}$} & Mean & 29.934 & 44.311 & \multirow[t]{2}{*}{-3.3343} & \multirow[t]{2}{*}{0.0011} \\
\hline & $\mathrm{SD}$ & 14.268 & 31.702 & & \\
\hline Countries & & $\mathrm{CZ}(\mathrm{N}=27)$ & $\operatorname{PL}(\mathrm{N}=87)$ & $\operatorname{SK}(\mathrm{N}=16)$ & \\
\hline \multirow{2}{*}{$\begin{array}{l}\text { Credit Period } \\
\text { (days) }\end{array}$} & Mean & 45.782 & 32.665 & 46.749 & \\
\hline & SD & 29.083 & 21.053 & 35.331 & \\
\hline ANOVA & $\mathrm{DF}$ & Sum of Sq. & Mean Sq. & F-Ratio & p-value \\
\hline Between (Country) & 2 & 5236.261 & 2618.130 & 4.2179 & 0.0168 \\
\hline Scheffe & \multicolumn{2}{|c|}{$\mathrm{DF}=127 \mathrm{MSE}=620.7208$} & & \multicolumn{2}{|l|}{ PL-SK } \\
\hline \multirow[t]{2}{*}{ Groups } & Statistics & Group A & Group B & \multirow[t]{2}{*}{ t-statistic } & \multirow[t]{2}{*}{ p-value } \\
\hline & & $(\mathrm{N}=65)$ & $(\mathrm{N}=65)$ & & \\
\hline \multirow{2}{*}{$\begin{array}{l}\text { Collection Period } \\
\text { (days) }\end{array}$} & Mean & 34.542 & 43.038 & \multirow[t]{2}{*}{-3.3623} & \multirow[t]{2}{*}{0.0010} \\
\hline & SD & 10.661 & 17.360 & & \\
\hline Countries & & $\mathrm{CZ}(\mathrm{N}=27)$ & $\operatorname{PL}(\mathrm{N}=87)$ & $\mathrm{SK}(\mathrm{N}=16)$ & \\
\hline \multirow{2}{*}{$\begin{array}{l}\text { Collection Period } \\
\text { (days) }\end{array}$} & Mean & 40.514 & 37.036 & 45.415 & \\
\hline & $\mathrm{SD}$ & 18.421 & 13.719 & 13.782 & \\
\hline ANOVA & DF & Sum of Sq. & Mean Sq. & F-Ratio & p-value \\
\hline Between (Country) & 2 & 1050.124 & 525.062 & 2.3937 & 0.0954 \\
\hline Scheffe & \multicolumn{3}{|c|}{$\mathrm{DF}=127 \quad \mathrm{MSE}=219.3512$} & \multicolumn{2}{|c|}{ No differences at $\alpha=0.05$} \\
\hline
\end{tabular}

Source: author's calculation

Table 8. Indicators of debt management.

It should be explained by cooperative character of Polish milk processing companies which are more closely related to farmers - milk producers.

The collection period measures the time between when a producer sells outputs and when producer receive the payment from its customers. The companies in the group A have significantly shorter collection period than the group B. It means that they manage their receivables better. There are no significant differences in the collection period between countries but Polish companies had the collection period shorter than 40 days. So, Polish milk processors had better debt management than Czech and Slovak companies.

Table 9 evaluates the financial management through indicators of solvency and liquidity. It clearly shows that there weren't any significant differences in liquidity and solvency. So, the financial management seems to be similar in both groups and countries. The capital structure is described in table 10 .

The share of current liabilities to total assets did not significantly differ between the groups and countries. It means that management used similar share of current liabilities as the source of funding. The current liabilities include short-term loans and short-term trade liabilities.
The share of loans to total assets was significantly lower in group A but it did not significantly differ between countries. Thus, the companies with dynamic efficiency improvement (A) used less external finance resources. Such strategy is very beneficial in times of crisis when many companies could have problems with settlement of debt service costs.

Finally, the analysis distinguishes between national and foreign ownership of milk processors. There should be a hypothesis that technical efficiency, technical improvement and profitability are higher in the companies owned by strong foreign capital than in the family-owned firms or companies with national equity. The main argument for the hypothesis is that the parent foreign company put more emphasize on optimization of production process and financial management of the subsidiary company. Moreover, the parent foreign company should manage investments in subsidiary company more efficiently. The table 11 shows results of Welch's modification of t-test with unequal variances.

The comparison reveals the significant differences between technical efficiency between the two groups. Companies with majority of foreign capital had significantly higher technical efficiency than 


\begin{tabular}{|c|c|c|c|c|c|}
\hline Groups & Statistics & $\begin{array}{l}\text { Group A } \\
(\mathrm{N}=65)\end{array}$ & $\begin{array}{l}\text { Group B } \\
(\mathrm{N}=65)\end{array}$ & t-statistic & $\mathrm{p}$-value \\
\hline \multirow[t]{2}{*}{ Liquidity Ratio (x) } & Mean & 1.365 & 1.072 & 0.9861 & 0.3259 \\
\hline & SD & 2.242 & 0.829 & & \\
\hline Countries & & $\mathrm{CZ}(\mathrm{N}=27)$ & $\operatorname{PL}(\mathrm{N}=87)$ & SK $(N=16)$ & \\
\hline \multirow[t]{2}{*}{ Liquidity Ratio (x) } & Mean & 1.108 & 1.315 & 0.880 & \\
\hline & SD & 0.686 & 2.000 & 0.797 & \\
\hline ANOVA & $\mathrm{DF}$ & Sum of Sq. & Mean Sq. & F-Ratio & $\mathrm{p}$-value \\
\hline Between (Country) & 2 & 2.968 & 1.484 & 0.5155 & 0.59844 \\
\hline Scheffe & \multicolumn{3}{|c|}{$\mathrm{DF}=127 \quad \mathrm{MSE}=2.878802$} & \multicolumn{2}{|c|}{ No differences at $\alpha=0.05$. } \\
\hline Groups & Statistics & $\begin{array}{l}\text { Group A } \\
(\mathrm{N}=65)\end{array}$ & $\begin{array}{l}\text { Group B } \\
(\mathrm{N}=65)\end{array}$ & t-statistic & p-value \\
\hline \multirow[t]{2}{*}{ Solvency Ratio (\%) } & Mean & 46.598 & 42.145 & 1.1212 & 0.2643 \\
\hline & $\mathrm{SD}$ & 22.204 & 23.075 & & \\
\hline Countries & & $\mathrm{CZ}(\mathrm{N}=27)$ & $\operatorname{PL}(\mathrm{N}=87)$ & SK $(N=16)$ & \\
\hline \multirow[t]{2}{*}{ Solvency Ratio (\%) } & Mean & 40.725 & 47.166 & 35.328 & \\
\hline & $\mathrm{SD}$ & 23.272 & 21.380 & 26.503 & \\
\hline ANOVA & DF & Sum of Sq. & Mean Sq. & F-Ratio & $\mathrm{p}$-value \\
\hline Between (Country) & 2 & 2346.831 & 1173.416 & 2.3312 & 0.10133 \\
\hline Scheffe & \multicolumn{3}{|c|}{$\mathrm{DF}=127 \mathrm{MSE}=503.3601$} & \multicolumn{2}{|c|}{ No differences at $\alpha=0.05$} \\
\hline
\end{tabular}

Source: author's calculation

Table 9: Statistics of liquidity and solvency.

\begin{tabular}{|c|c|c|c|c|c|}
\hline Groups & Statistics & $\begin{array}{l}\text { Group A } \\
(\mathrm{N}=65)\end{array}$ & $\begin{array}{l}\text { Group B } \\
(\mathrm{N}=65)\end{array}$ & t-statistic & p-value \\
\hline \multirow{2}{*}{$\begin{array}{l}\text { Current liabilities / } \\
\text { Total assets (\%) }\end{array}$} & Mean & 42.075 & 48.301 & \multirow[t]{2}{*}{-1.4550} & \multirow[t]{2}{*}{0.1481} \\
\hline & SD & 16.909 & 30.072 & & \\
\hline Countries & & $\mathrm{CZ}(\mathrm{N}=27)$ & $\operatorname{PL}(\mathrm{N}=87)$ & SK $(N=16)$ & \\
\hline \multirow{2}{*}{$\begin{array}{l}\text { Current liabilities / } \\
\text { Total assets (\%) }\end{array}$} & Mean & 48.334 & 42.795 & 52.893 & \\
\hline & SD & 22.008 & 25.219 & 23.707 & \\
\hline ANOVA & DF & Sum of Sq. & Mean Sq. & F-Ratio & p-value \\
\hline Between (Country) & 2 & 1715.349 & 857.675 & 1.4385 & 0.24111 \\
\hline Scheffe & \multicolumn{2}{|c|}{$\mathrm{DF}=127 \quad \mathrm{MSE}=596.2081$} & & \multicolumn{2}{|c|}{ No differences at $\alpha=0.05$} \\
\hline Groups & Statistics & $\begin{array}{l}\text { Group A } \\
(\mathrm{N}=65)\end{array}$ & $\begin{array}{l}\text { Group B } \\
(\mathrm{N}=65)\end{array}$ & t-statistic & p-value \\
\hline \multirow{2}{*}{$\begin{array}{l}\text { Loans / Total } \\
\text { Assets (\%) }\end{array}$} & Mean & 4.346 & 11.030 & \multirow[t]{2}{*}{-3.0006} & \multirow[t]{2}{*}{0.0032} \\
\hline & SD & 6.807 & 16.619 & & \\
\hline Countries & & $\mathrm{CZ}(\mathrm{N}=27)$ & $\operatorname{PL}(\mathrm{N}=87)$ & SK $(N=16)$ & \\
\hline \multirow{2}{*}{$\begin{array}{l}\text { Loans / Total } \\
\text { Assets (\%) }\end{array}$} & Mean & 8.913 & 6.554 & 11.784 & \\
\hline & SD & 9.336 & 14.338 & 10.735 & \\
\hline ANOVA & DF & Sum of Sq. & Mean Sq. & F-Ratio & p-value \\
\hline Between (Country) & 2 & 420.853 & 210.426 & 1.2330 & 0.29488 \\
\hline Scheffe & \multicolumn{3}{|c|}{$\mathrm{DF}=127 \quad \mathrm{MSE}=170.6631$} & \multicolumn{2}{|c|}{ No differences at $\alpha=0.05$} \\
\hline
\end{tabular}

Source: author's calculation

Table 10: Statistics of the capital structure. 


\begin{tabular}{|lccccc|}
\hline Indicator & Statistics & $\begin{array}{c}\text { Foreign } \\
(\mathrm{N}=15)\end{array}$ & $\begin{array}{c}\text { National } \\
(\mathrm{N}=115)\end{array}$ & t-statistic & p-value \\
\hline ROA (\%) & Mean & 3.821 & 2.817 & 0.5103 & 0.6152 \\
& $\mathrm{SD}$ & 6.967 & 8.575 & & 0.0112 \\
\hline TE (\%) & Mean & 89.974 & 82.723 & 2.8356 & 0.3261 \\
\hline Malmquist index & $\mathrm{SD}$ & 9.416 & 8.497 & & -1.0142 \\
& Mean & 1.014 & 1.036 & & 0.048 \\
\hline
\end{tabular}

Source: author's calculation

Table 11: Comparison of milk processors with national and foreign ownership (2008 - 2013).

milk processors with national ownership. However, there were no significant differences in ROA and Malmquist index.

The limitation of the research is that the analysis does not comprise milk products sold under private labels in large grocery retailers (hypermarkets), such as Tesco (Tesco Stores ČR a.s., Tesco Polska Sp z.o.o., Tesco Stores SR a.s.), and discounters (Lidl Česká republika v.o.s., Lidl Polska Sklepy Spozywcze Sp z.o.o. Spk, Lidl Slovenská republika, v.o.s.; Kaufland Ceska republika v.o.s., Kaufland Polska Markety Sp z.o.o. Spk, Kaufland Slovenská republika v.o.s.). The trade flows within the vertical of milk products in the large multinational grocery retailers enable to produce even cheaper than in conventional customer-supplier vertical.

\section{Conclusion}

The aim of the article was to evaluate the efficiency improvement of the Czech, Polish and Slovak milk processors through DEA and Malmquist index. The analysis of 130 medium and large corporate milk processors in the NACE 10.51 covered the period 2008 - 2013 as the major part of the "old" programming period of the RDP. The analysis of the technical efficiency was completed by the financial analysis.

The results clearly proved that Polish milk processors had significantly more dynamic technical improvement than Czech and Slovak companies. An important finding was that the investment activity did not significantly affect the efficiency improvement. Unlike Czech and Slovak companies, Polish milk processors have continuously increased the technical efficiency from $66.6 \%$ (2008) to $90.9 \%$ (2013). Thus, Polish milk processors can be considered as very successful in technical efficiency improvement. The partial productivity revealed the significant role of high capital productivity in Poland in 2012 and 2013. So, capital productivity is one of the main determinants of technical efficiency and improvement. The success of Polish milk processors could even deepen the future negative trade balance of milk products in the Czech Republic and Slovakia.

The statistical comparison indicates different strategy of financial management and marketing. The Czech milk processors had high profitability and profit margin and quite low stock turnover. Alternatively, Slovak milk processors had very low profit margin (loss) and quick stock turnover. Polish milk processors had balanced profit margin and stock turnover. However, differences in stock turnover between countries were not statistically significant.

Indicators of debt management proved significant differences in collection period and credit period between the group A and B. The group A had better payment morale than group B and was able to get receivables quicker. Polish milk processor had different debt strategy from the Czech and Slovak companies. It should be explained by cooperative character of Polish milk processing companies which are more closely related to farmers - owners of milk processing capacities.

The group A used significantly less loans to finance total assets than the group B. It means that higher technical improvement was achieved by less use of bank loans. It is interesting conclusion that is partially influenced by the crisis period in 2008 2013 as the companies with lower debt were more viable than indebted ones.

An important finding is that companies with majority of foreign capital had higher technical efficiency than companies owned by national investor. However, there were no differences in technical progress. So, government should consider more the criterion of ownership independence in order to support national family and non-family companies which are not financed by foreign capital. 
The results establish arguments to the Ministry of Agriculture to support investments towards technology of milk processing. For example, the Czech Rural Development Programme in the period 2014 - 2020 offers 98 mil. EUR of public support for investments in processing/ marketing and/or development of agricultural products and 70.88 mil. EUR of public support for pilot projects/the development of new products, practices, processes and technologies in processing of agricultural products. The same suggestion should be targeted at Slovak Ministry.

\section{Acknowledgements}

The article was supported by the institutional support of the University of Economics, Prague, project no. VŠE IP300040.

\section{Corresponding author:}

Doc. Ing. Jindřich Špička, Ph.D.

Faculty of Business Administration, University of Economics, Prague

W. Churchill Sq. 4, 130 67, Prague 3, Czech Republic

Phone: +42022409 8650,E-mail: jindrich.spicka@vse.cz

\section{References}

[1] Baráth, L., Ferto, I. Heterogeneous technology, scale of land use and technical efficiency: The case of Hungarian crop farms. Land Use Policy. 2015, Vol. 42, No. 1, p. 141-150. ISSN 0264-8377.

[2] Bureau van Dijk. Amadeus database: Company information and business intelligence, 2015 [Online] Available: http://www.bvdinfo.com/en-gb/home [Accessed 15 Jan 2015].

[3] Bojnec, S., Ferto, I., Jámbor, A., Tóth, J. Determinants of technical efficiency in agriculture in new EU member states from Central and Eastern Europe. Acta Oeconomica. 2014, Vol. 64, No. 2, p. 197-217. ISSN 0001-6373.

[4] Caves, D. W, Christensen, L. R., Diewert, W. E. The economic theory of index numbers and the measurement of input, output, and productivity. Economica. 1982, Vol. 50, No. 6, p. 1393-1414. ISSN 0013-0427.

[5] Czech Statistical Office. External Trade Database: Czech Republic. 2015 [Online] Available: https://www.czso.cz/csu/czso/home [Accessed 10 Feb 2015].

[6] Čechura L., Hockmann H. Sources of economical growth in the Czech food processing. Prague Economic Papers. 2010, Vol. 19, No. 2, p. 169-182. ISSN 1210-0455.

[7] Čechura, L., Malá Z. Technology and efficiency comparison of Czech and Slovak processing companies. Procedia Economics and Finance. 2014, Vol. 12, p. 93-102. ISSN 2212-5671.

[8] Čechura, L. Technical efficiency and total factor productivity in Czech agriculture. Agricultural Economics - Zemědělská ekonomika. 2012, Vol. 58, No. 4, p. 147-156. ISSN 0139-570X.

[9] Daňková, A., Bosáková, Z. The competitiveness of the chosen processing branches Slovak food industry. Ekonomický časopis, 2005, Vol. 53, No. 4, p. 415-426. ISSN 0013-3035.

[10] Eurostat. Short-term business statistics. 2015 [Online] Available: http://ec.europa.eu/eurostat/web/short-term-business-statistics [Accessed 25 Feb 2015].

[11] Färe, R., Grosskopf, S., Lindgren, B., Roos, P. Productivity changes in Swedish pharamacies 1980-1989: A non-parametric Malmquist approach. Journal of Productivity Analysis. 1992, Vol. 3, No. 1-2, p. 85-101. ISSN 0895-562X.

[12] Ferrier, G. D., Porter, P. K. The productive efficiency of United-states milk processing cooperatives. Journal of Agricultural Economics. 1991, Vol. 42, No. 2, p. 161-173. ISSN 0021-857X.

[13] Forsund, F. R., Hjalmarsson, L. Generalized Farrell measures of efficiency - application to milk processing in Swedish dairy plants. Economic Journal, 1979, Vol. 89, No. 354, p. 294-315. ISSN 0013-0133. 
[14] Machek, O. The relationship between financial performance and total factor productivity: evidence from the Czech agricultural sector. International Journal of Social Sciences and Humanity Studies, 2014, Vol. 6, No. 2, p. 57-57. ISSN 2220-8488.

[15] Maxová, J., Žáková Kroupová, Z. Performance of Czech dairy farms. In Smutka, L., Řezbová, H. (ed.) Agrarian Perspectives XXIV. - Global Agribusiness and the Rural Economy. Proceedings of the $24^{\text {th }}$ International Scientific Conference, September 16 - 18, 2015, Czech University of Life Sciences Prague, p. 273-281. ISBN 978-80-213-2581-4, ISSN 2464-4781 (Online). Available: http://ap.pef.czu.cz/static/proceedings/2015/ [Accessed: 05 Oct. 2015].

[16] Nastasenko, A. G. Methodic approach to estimation of investment activity efficiency of milk-processing enterprises. Actual Problems of Economics. 2010, Vol. 106, No. 1, p. 120-126. ISSN 1993-6788.

[17] Nečadová, M. Selected approaches to measurement of national competitiveness and the results of Visegrad Group in years 2007-2014. Acta Oeconomica Pragensia. 2015, Vol. 23, No. 2, p. 22-39. ISSN 0572-3043.

[18] Nowak, A., Kijek, T., Domańska, K. Technical efficiency and its determinants in the European Union agriculture. Agricultural Economics - Zemědělská ekonomika. 2015, Vol. 6, No. 6, p. 275-283. ISSN 0139-570X.

[19] Rosner, B. Fundamentals of biostatistics. $7^{\text {th }}$ edition. Brooks/Cole. New York, 2011.

[20] Špička, J., Machek, O. Change in the production efficiency of European specialized milk farming. Agricultural Economics - Zemědělská ekonomika. 2015, Vol. 61, No. 1, p. 1-13. ISSN 0139-570X. 